\title{
STIGMA SCALE OF EPILEPSY
}

\section{The perception of epilepsy stigma in different cities in Brazil}

\author{
Paula T. Fernandes ${ }^{1,2}$, Ana Lúcia A. Noronha, , Josemir W. Sander, ${ }^{3,4}$ Li M. Li, ${ }^{1,2}$
}

\begin{abstract}
Purpose: To assess the perception of epilepsy stigma in different regions of Brazil. Method: The Stigma Scale of Epilepsy (SSE) questionnaire was applied to people in different Brazilian urban settings. The survey was performed on individual basis; an interviewer read the questions to the subjects and wrote down the answers. The same procedure was applied to all the subjects and took around 10 minutes. Results: 266 questionnaires were completed in four different towns of Brazil (Curitiba=83; São Paulo=47; Vila Velha=79; Ipatinga =57). The overall stigma score was 49.7 (median). Different scores were obtained in each locality. Vila Velha=42; Curitiba=49; São Paulo=52; Ipatinga=54 (ANOVA [2.262]=3.82; $p=0.01$ ). Conclusion: This study showed differences in the perception of stigma, which may depend on cultural and regional aspects. The concept of stigma has cultural perspectives, depending on the region and the context where each person lives. The understanding of this aspect of epilepsy is important to promote better de-stigmatization campaigns, considering the cultural and social differences.
\end{abstract}

KEY WORDS: stigma, epilepsy, stigma scale, quality of life.

\section{Percepção do estigma na epilepsia em diferentes cidades do Brasil}

Resumo - Objetivo: Identificar a percepção do estigma na epilepsia em diferentes regiões do Brasil. Método: A Escala de Estigma na Epilepsia foi aplicada em 266 pessoas de quatro diferentes cidades do Brasil (Curitiba, São Paulo, Vila Velha e Ipatinga). Em todas as situações, as pessoas foram entrevistadas individualmente, sendo que as questões eram lidas para os sujeitos. As condições de aplicação foram as mesmas nas cidades e a aplicação durou aproximadamente 10 minutos. Resultados: Foram aplicados 266 questionários em três diferentes cidades do Brasil (Curitiba=83; São Paulo=47; Vila Velha=79; Ipatinga=57). A média do escore geral da EEE foi 49,7. Na avaliação das quatro cidades separadamente, houve diferença significativa entre elas: Vila Velha=42; Curitiba=49; São Paulo=52 e Ipatinga=54 (ANOVA $[2,262]=3,82 ; p=0,01$ ). Conclusão: Este estudo mostrou diferenças na percepção do estigma, de acordo com as diferenças culturais e regionais. Neste contexto, podemos falar de uma perspectiva cultural para o conceito de estigma, sendo influenciado pela região e pelo contexto no qual a pessoa está inserida. O entendimento deste processo do estigma é importante para se propor campanhas efetivas de intervenção no estigma da epilepsia, considerando as diferenças sociais e culturais.

PALAVRAS-CHAVE: estigma, epilepsia, escala de estigma, qualidade de vida.

Throughout history, a diagnosis of epilepsy has carried a high level of social stigma. This may affect quality of life and psycho-social adjustment of people with epilepsy ${ }^{1-4}$. Misinformation and negative attitudes towards epilepsy are common over the world and contribute to discrimination against people with epilepsy ${ }^{5,6}$. These psycho-social difficulties are often considered more stressful and harmful than seizures themselves ${ }^{7-10}$. Stigma refers to a personal characteristic that marks a person as being dif- ferent and epilepsy is said to be a stigmatizing condition, because people in general are not used to seeing uncontrolled and unexpected seizures ${ }^{11}$.

Lack of correct information is one of the factors that may elicit stigma in epilepsy. A number of studies have reported that the psycho-social adjustment of people of epilepsy can be compromised by discrimination in employment and relationships, causing problems for their wellbeing ${ }^{1,912-14}$. Findings show that epilepsy stigma is related

\footnotetext{
'Departament of Neurology - State University of Campinas, Campinas SP, Brazil (UNICAMP); ${ }^{2}$ Assistência à Saúde de Pacientes com Epilepsia, Campinas SP, Brazil (ASPE); ${ }^{3}$ Epilepsy Institute of the Netherlands, SEIN, Heemstede, Achterweg 5, 2103 SW Heemstede, the Netherlands; ${ }^{4}$ Department of Clinical and Experimental Epilepsy, UCL Institute of Neurology, London UK.
}

Received 13 February 2008. Accepted 23 May 2008.

Dra. Paula T. Fernandes - Department of Neurology / UNICAMP - Cx. Postal 6111 - 13083-970 Campinas SP - Brasil. E-mail: paula@aspebrasil.org Site: http://www.aspebrasil.org 
not just to the lack of information, but also to the interpretation and people's behaviors in several situations. One review in developed countries highlighted the importance of psycho-social aspects in the development of stigma process in people with epilepsy ${ }^{12}$. Little research has been performed in resource-poor countries, but it is estimated that people with epilepsy experience problems with education, marriage, social relations and work ${ }^{9,2,15}$. It is known that having irrational beliefs and lack of information regarding epilepsy is one common pattern in resourcepoor countries ${ }^{16}$. It is therefore important in a study of stigma to focus not only on the person who is stigmatized, but especially on those who do the stigmatizing ${ }^{14}$.

This study is a part of process to identify the epilepsy stigma in our culture. With the design and validation of a Stigma Scale of Epilepsy ${ }^{7,9,17-20}$, we have now the tools to assess whether there are differences in epilepsy stigma in different areas of Brazil.

\section{METHOD}

\section{Subjects}

People in four urban settings in Brazil: Curitiba (State capital of Paraná), São Paulo (State capital of São Paulo) and Vila Velha (Espírito Santo State), Ipatinga (Minas Gerais State).

\section{Instrument}

The Stigma Scale of Epilepsy (SSE), which was designed and validated by our group ${ }^{9,17}$ was used. It contains questions about the perception of epilepsy in the community, and the scores give the level of stigma perceived by each person. Individuals were asked to indicate the most appropriate class of answers for each item, marking the number that corresponding to the category (1=not at all, 2=a little, 3=a lot, 4=totally). The SSE scores range from 0 (no stigma) to 100 (maximum stigma), and are independent of the number of questions answered. An additional question asked 'Do you think that people with epilepsy are stigmatized by society?'

The questionnaire included questions about personal data (age, profession, sex, religion, school level, socioeconomic condition) and one question applied only to people with epilepsy, since it refers to characteristics of their condition, such as age at the onset of seizures, type of seizure and medication. Respondents were classified into socio-economic classes, using a validated questionnaire based on household possessions ${ }^{21}$. There are seven socio-economic classes, as shown in Table 1.

\section{Assessment}

The four locations were chosen as the local epilepsy associations provided support. The associations' coordinators asked randomly selected people on the streets in the centre of the respective towns to complete the questionnaires.

Power analysis suggested that 47 respondents in each town would be sufficient to provide statistical significance if real dif-
Table 1. Socio-economic classes.

\begin{tabular}{cc}
\hline $\begin{array}{c}\text { Socio-economic } \\
\text { classes }\end{array}$ & $\begin{array}{c}\text { Family monthly income } \\
\text { (in Brazilian Reais) }\end{array}$ \\
\hline A1 & R\$ 7,793.00 \\
A2 & R\$ 4,648.00 \\
B1 & $R \$ 2,804.00$ \\
B2 & $R \$ 1,669.00$ \\
C & $R \$ 927.00$ \\
D & $R \$ 424.00$ \\
E & $R \$ 207.00$ \\
\hline
\end{tabular}

US\$ $1.00=B R L 2.00$

ferences existed. This survey was performed on an individual basis; an interviewer read the questions to the subjects who wrote down the answers. The procedure was the same for all the subjects and took around 10 minutes.

The Ethics Committee of Unicamp approved the study (number 064/2002).

\section{RESULTS}

266 questionnaires were completed (Curitiba=83 subjects; São Paulo=47 subjects; Vila Velha=79 subjects; Ipatinga $=57$ subjects). The main characteristics of the respondents are shown in Table 2.

Table 3 highlights the subjects' answers using a scale from 1 to 4 (not at all to totally) in the four locations.

The median of the overall stigma score was 49.7. There were statistical differences between the four localities: Vila Velha=42 (Cl 95\%: 11.1-91.7); Curitiba=49 (Cl 95\%: 12.587.5); São Paulo=52 (Cl 95\%: 15.3-83.3); Ipatinga=54 (Cl

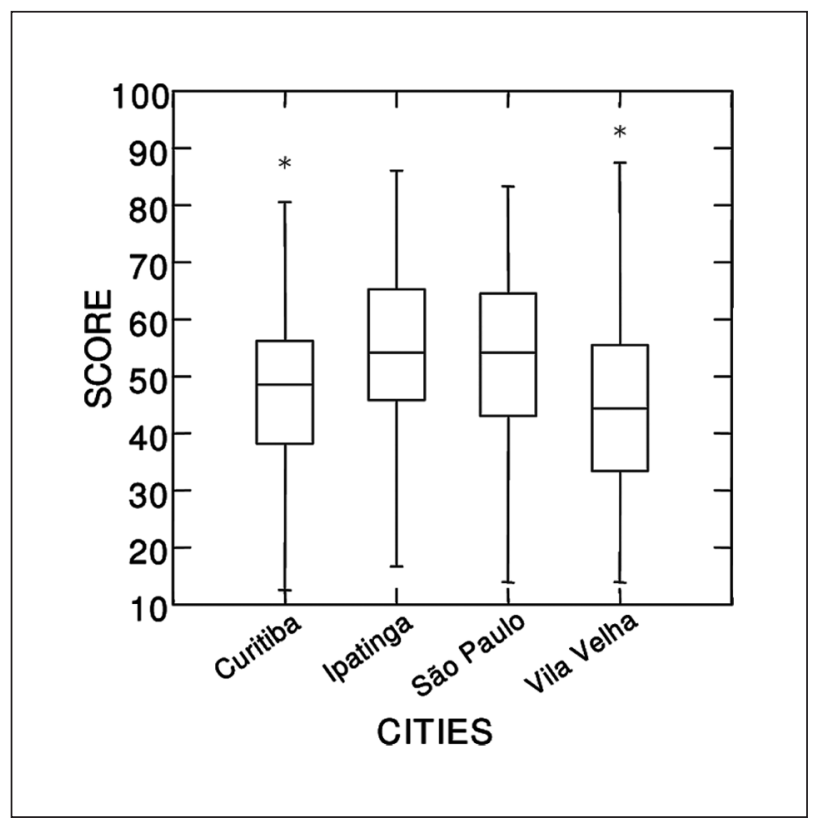

Fig 1. Different perception of stigma in four cities. 
Table 2. Characteristics of the subjects in different towns.

\begin{tabular}{|c|c|c|c|c|}
\hline \multirow[t]{2}{*}{ Characteristics } & \multicolumn{4}{|c|}{ Subjects (\%) } \\
\hline & $\mathrm{C}$ & SP & VV & I \\
\hline Mean age & 26 & 43 & 29 & 39 \\
\hline $\mathrm{Cl}$ (Confidence interval) & $17-48$ & $18-77$ & $18-58$ & $17-73$ \\
\hline SD (Standard deviation) & 7.49 & 16.02 & 10.0 & 15.2 \\
\hline \multicolumn{5}{|l|}{ Gender } \\
\hline Female & 97.6 & 59.6 & 46.8 & 42.1 \\
\hline Male & 2.4 & 40.4 & 53.2 & 57.8 \\
\hline \multicolumn{5}{|l|}{ Religion } \\
\hline Catholic & 72.3 & 46.8 & 49.4 & 49.1 \\
\hline Evangelical & 16.9 & 14.9 & 29.1 & 42.1 \\
\hline Spiritist & 4.8 & 12.8 & 6.3 & 0 \\
\hline Others & 1.2 & 4.3 & 7.6 & 0 \\
\hline No religion & 4.8 & 21.3 & 7.6 & 8.8 \\
\hline \multicolumn{5}{|l|}{ Educational level } \\
\hline Illiterate/incomplete elementary school & 0 & 6.4 & 0 & 19.3 \\
\hline Complete elementary school/incomplete high school & 1.2 & 19.2 & 0 & 21.1 \\
\hline Complete high school/incomplete college & 2.4 & 25.6 & 3.8 & 14.0 \\
\hline Complete college/incomplete university degree & 92.8 & 19.1 & 78.5 & 35.1 \\
\hline University degree & 1.2 & 29.7 & 17.7 & 10.5 \\
\hline No answer & 2.4 & 0 & 0 & 0 \\
\hline \multicolumn{5}{|l|}{ Social class } \\
\hline $\mathrm{A} 1$ & 1.2 & 6.4 & 1.3 & 0 \\
\hline $\mathrm{A} 2$ & 7.2 & 4.3 & 22.8 & 7.0 \\
\hline B1 & 21.7 & 10.6 & 22.8 & 8.8 \\
\hline B2 & 39.8 & 19.1 & 26.6 & 19.3 \\
\hline $\mathrm{C}$ & 28.9 & 36.2 & 21.5 & 38.6 \\
\hline $\mathrm{D}$ & 0 & 19.1 & 1.3 & 26.3 \\
\hline $\mathrm{E}$ & 0 & 4.3 & 0 & 0 \\
\hline No answer & 1.2 & 0 & 3.8 & 0 \\
\hline \multicolumn{5}{|l|}{ Familiarity with epilepsy } \\
\hline Patient with epilepsy & 1.2 & 17.0 & 2.5 & 1.03 \\
\hline Relatives & 12.0 & 25.5 & 16.5 & 12.2 \\
\hline Health professional & 1.2 & 2.1 & 3.8 & 1.5 \\
\hline Educational professional & 37.4 & 2.1 & 1.3 & 0 \\
\hline Other & 48.2 & 53.1 & 75.9 & 85.0 \\
\hline
\end{tabular}

C, Curitiba; SP, São Paulo; VV, Vila Velha; I, Ipatinga. The results are presented in percentage

95\%: 16.67-86.11) (ANOVA [2.262]=3.82; $p=0.01$ ). Vila Velha showed the lowest perception of stigma compared with the other three towns (Tukey's: Vila Velha $<$ Curitiba=São Paulo=Ipatinga), as illustrated in Figure 1.

Analyzing the four towns separately shows the following. The Figure 2 shows these results.

VILA VELHA: No significant differences were found between the overall score and religion [ANOVA (4.70)=1.21; $p=0.32$ ], gender [ANOVA (1.73) $=1.35 ; p=0.25]$, social class [ANOVA (2.54) $=5.69 ; p=0.89]$ and school level of the subjects [ANOVA (2.54) $=1.50 ; p=0.23]$. In relation to familiarity with epilepsy, significant differences were not observed [ANOVA (3.52) $=1.31 ; p=0.28$ ].

CURITIBA: As shown in Figure 3, there were no significant differences between the SSE score and religion [ANOVA $(3.77)=0.97 ; p=0.4$ ], gender [ANOVA (1.79) $=0.28 ; p=0.60$ ], social class [ANOVA (4.76) $=0.89 ; p=0.48]$ and school level [ANOVA (2.78) $=0.63 ; p=0.54$ ] of the subjects. In this town, the perception of epilepsy stigma changed with the epilepsy familiarity [ANOVA (2.67) $=4.47 ; p=0.02$; Tukey's=no familiarity $>$ educational professionals $>$ relatives].

SÃO PAULO: There were no differences between the overall score of SSE and religion [ANOVA (4.42) $=0.61 ; p=0.66$ ], gender [ANOVA (1.45) $=1.47 ; p=0.23$ ], social class [ANOVA $(5.41)=1.87 ; p=0.12]$ and school level [ANOVA (4.42)=0.30; $\mathrm{p}=0.88$ ] of the subjects (Fig 4). The familiarity with epilepsy showed no differences [ANOVA (2.33) $=2.55 ; p=0.09$ ].

IPATINGA: There were no differences between the over- 
Table 3. Subjects' perceptions about epilepsy in different towns (shown as percentage).

\begin{tabular}{|c|c|c|c|c|c|c|c|c|c|c|c|c|c|c|c|}
\hline \multicolumn{4}{|c|}{ Not at all } & \multicolumn{4}{|c|}{ A little } & \multicolumn{4}{|c|}{ A lot } & \multicolumn{4}{|c|}{ Totally } \\
\hline C & SP & VV & I & C & SP & VV & I & C & SP & VV & I & $C$ & SP & VV & I \\
\hline
\end{tabular}

Do you think that people with epilepsy feel able to control their own epilepsy?

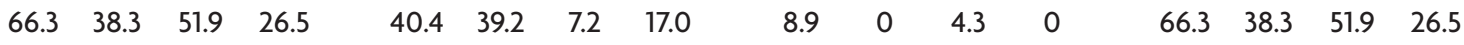

How would you feel when you see an epileptic seizure?

$\begin{array}{lcccccccccccccccc}\text { Shock } & 14.5 & 31.9 & 24.1 & 45.6 & 39.8 & 27.7 & 55.7 & 14.0 & 33.7 & 25.5 & 12.7 & 24.6 & 12.0 & 14.9 & 7.6 & 15.8 \\ \text { Fear } & 47.0 & 42.6 & 63.3 & 80.4 & 31.3 & 29.8 & 21.5 & 7.1 & 15.7 & 12.8 & 11.4 & 8.9 & 6.0 & 14.9 & 3.8 & 3.6 \\ \text { Sadness } & 22.9 & 25.5 & 20.3 & 17.6 & 28.9 & 42.6 & 34.2 & 14.0 & 28.9 & 17.0 & 25.3 & 40.3 & 19.3 & 14.9 & 20.3 & 28.1 \\ \text { Pity } & 34.9 & 38.3 & 40.5 & 19.4 & 22.9 & 31.9 & 27.8 & 24.6 & 18.1 & 8.5 & 11.4 & 14.0 & 24.1 & 21.3 & 20.3 & 42.1\end{array}$

Which difficulties do you think people with epilepsy have in their daily lives?

\begin{tabular}{|c|c|c|c|c|c|c|c|c|c|c|c|c|c|c|c|c|}
\hline Relationships & 44.6 & 29.8 & 50.6 & 36.8 & 37.4 & 40.4 & 32.9 & 22.8 & 14.4 & 23.4 & 12.7 & 29.8 & 3.6 & 6.4 & 3.8 & 10.5 \\
\hline Work & 3.6 & 0 & 5.1 & 1.7 & 21.7 & 17.0 & 31.6 & 8.8 & 43.4 & 23.4 & 38.0 & 19.3 & 31.3 & 59.6 & 25.3 & 70.2 \\
\hline School & 4.8 & 4.3 & 15.2 & 5.3 & 44.6 & 42.6 & 32.9 & 22.8 & 37.3 & 40.4 & 36.7 & 40.3 & 13.3 & 12.8 & 15.2 & 31.6 \\
\hline Friendship & 18.1 & 17.0 & 20.3 & 14.3 & 31.3 & 27.7 & 31.6 & 17.8 & 28.9 & 31.9 & 30.4 & 25.0 & 21.7 & 23.4 & 17.7 & 42.9 \\
\hline Sexual & 26.5 & 34.8 & 38.0 & 26.3 & 37.3 & 34.8 & 26.6 & 26.3 & 21.7 & 23.9 & 24.1 & 35.1 & 14.5 & 6.5 & 11.4 & 12.3 \\
\hline Emotional & 4.8 & 14.9 & 10.1 & 8.8 & 21.7 & 23.4 & 30.4 & 12.3 & 45.8 & 36.2 & 34.2 & 45.6 & 27.7 & 25.5 & 25.3 & \\
\hline Prejudice & 4.8 & 8.7 & 12.7 & 8.8 & 12.0 & 10.9 & 21.5 & 12.3 & 39.8 & 26.1 & 26.6 & 17.6 & 43.4 & 54.3 & 39.2 & \\
\hline
\end{tabular}

How do you think that people with epilepsy feel?

\begin{tabular}{|c|c|c|c|c|c|c|c|c|c|c|c|c|c|c|c|c|}
\hline Worried & 6.0 & 10.6 & 8.9 & 7.0 & 37.3 & 19.1 & 40.5 & 26.3 & 42.2 & 36.2 & 29.1 & 50.9 & 14.5 & 34.0 & 21.5 & 15.8 \\
\hline Dependent & 27.7 & 14.9 & 17.7 & 29.8 & 34.9 & 42.6 & 45.6 & 17.5 & 32.6 & 27.2 & 27.8 & 31.6 & 4.8 & 14.9 & 8.9 & 21.1 \\
\hline Incapable & 56.7 & 48.9 & 50.6 & 66.7 & 30.1 & 19.1 & 30.4 & 17.5 & 8.4 & 21.3 & 12.4 & 10.5 & 4.8 & 10.6 & 6.3 & 5.3 \\
\hline Fearful & 13.2 & 17.0 & 16.5 & 15.8 & 39.8 & 25.5 & 44.3 & 38.6 & 33.8 & 29.8 & 21.5 & 29.8 & 13.2 & 27.7 & 17.7 & 15.8 \\
\hline Ashamed & 14.5 & 12.8 & 21.5 & 8.8 & 43.4 & 38.3 & 31.6 & 17.5 & 28.9 & 25.5 & 22.8 & 40.4 & 13.2 & 23.4 & 24.1 & 33.3 \\
\hline Depressed & 13.2 & 14.9 & 29.1 & 12.3 & 50.6 & 29.8 & 35.4 & 24.6 & 24.1 & 40.4 & 24.1 & 40.4 & 12.1 & 14.9 & 11.4 & 22.8 \\
\hline The same & 53.1 & 42.6 & 36.7 & 22.8 & 30.1 & 36.2 & 30.4 & 7.1 & 9.6 & 14.9 & 13.9 & 33.3 & 7.2 & 6.4 & 17.7 & 36.8 \\
\hline \multicolumn{17}{|c|}{ In your opinion, the prejudice in epilepsy will be related to } \\
\hline Relationships & 7.2 & 10.6 & 8.9 & 14.3 & 33.7 & 34.0 & 32.9 & 25.0 & 39.8 & 27.7 & 41.8 & 30.4 & 19.3 & 27.7 & 16.5 & 30.4 \\
\hline Marriage & 42.2 & 25.5 & 46.8 & 26.8 & 39.7 & 38.3 & 32.9 & 46.4 & 15.7 & 8.5 & 15.2 & 19.6 & 2.4 & 27.7 & 5.1 & 7.2 \\
\hline Work & 8.5 & 2.1 & 8.9 & 8.9 & 36.1 & 12.8 & 36.7 & 8.9 & 34.9 & 25.5 & 34.2 & 44.6 & 20.5 & 59.6 & 20.3 & 37.5 \\
\hline School & 4.8 & 4.3 & 2.5 & 8.9 & 42.2 & 23.4 & 31.6 & 25.0 & 42.2 & 44.7 & 45.6 & 50.0 & 10.8 & 27.7 & 20.3 & 16.1 \\
\hline Family & 45.8 & 32.6 & 65.8 & 57.1 & 43.4 & 43.5 & 25.3 & 25.0 & 9.6 & 17.4 & 7.6 & 14.3 & 1.2 & 6.5 & 1.3 & 3.6 \\
\hline
\end{tabular}

C, Curitiba; SP, São Paulo; VV, Vila Velha; I, Ipatinga. The results are presented in percentage.

all score of SSE and religion [ANOVA (2.54) $=0.14, p=0.87$ ] or gender [ANOVA (1.55)=1.46, $\mathrm{p}=0.23$ ]. There were significant statistical differences between overall SSE scores in social class [ANOVA (1.55)=3.18, $p=0.02$ ] and school level [ANOVA (4.52)=4.27, $\mathrm{p}<0.001]$. The familiarity with epilepsy showed no differences [ $t$ test $(52)=19.7 ; p=0.32$ ].

In all cities, we observed that the general SSE score was higher in those who perceived stigma in society. This was estimating comparing the answer to the question "Do you think that people with epilepsy are stigmatized by the society?" with the general score; the results are shown in Figure 3. When people believe that there is prejudice in the community, their perception of epilepsy stigma is high.

\section{DISCUSSION}

This study was performed to assess possible differences between the degree of epilepsy stigma found in four Brazilian localities and showed some differences in the perception of stigma, which may vary according to cultural and regional aspects. We confirmed the results of previous studies ${ }^{22}$, which showed that stigma can be heterogeneous and changeable, depending on social factors.

Although there are few studies in resource-poor countries, a review of the literature suggests that people with epilepsy experience problems with marriage, education, social isolation and employment ${ }^{9}$. Thus epilepsy is a condition that influences the perception of health and people's quality of life.

Our study showed that the main aspects related to epilepsy stigma were difficulties in work and relationships, which may be culturally and regionally determined.

These results confirm the results of our previous epidemiologic survey performed in Campinas ${ }^{7,9,17}$ (State of São Paulo, Brazil) with 1,850 people. The general stigma 


\section{VILA VELHA}

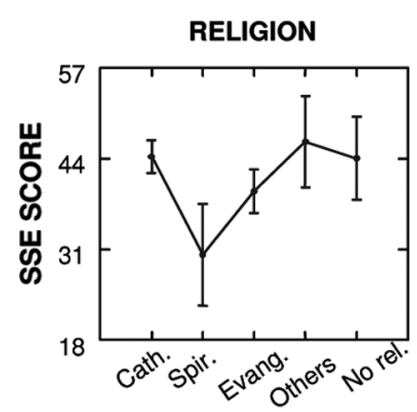

\section{CURITIBA}
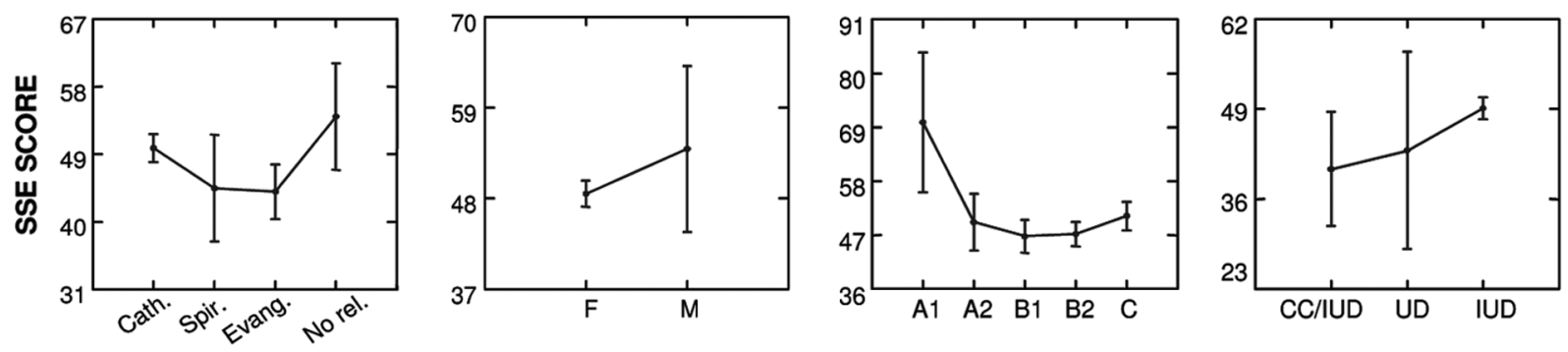

\section{$\underline{\text { SÃO PAULO }}$}
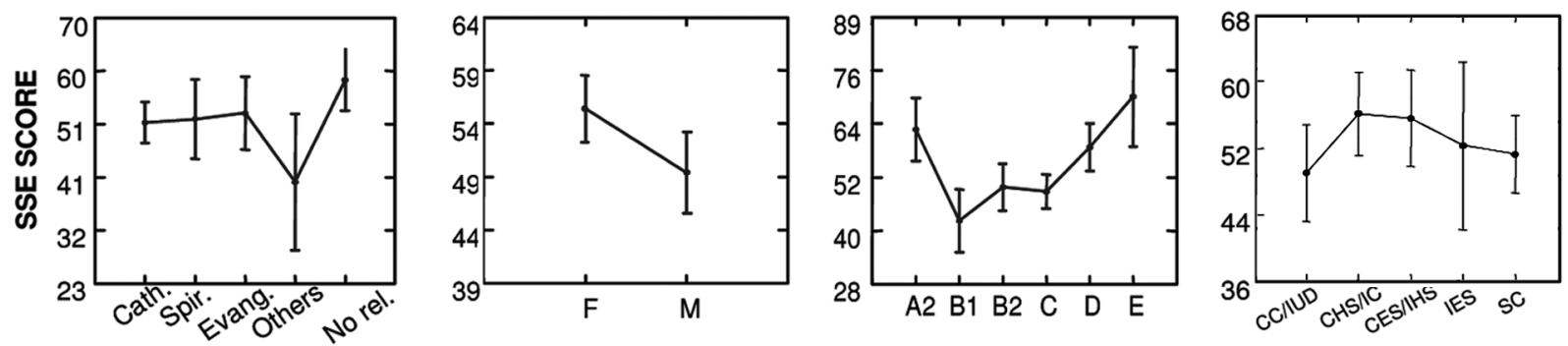

\section{IPATINGA}
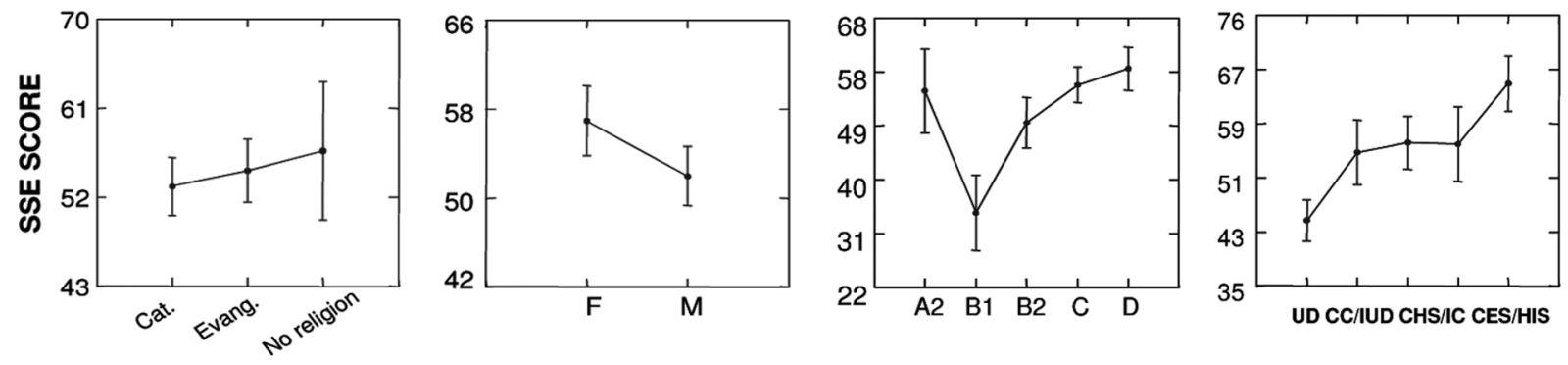

Fig 2. Comparison between religion, gender, social class and school level in four cities (Least Square Means). Religion: Cath, Catholic; Spir, Spiritist; Evang, Evangelical; Others, Other Religions; No rel, No religion. School level: IES, Incomplete Elementary school; CES/IHS, Complete Elementary School/Incomplete High School; CHS/IC, Complete High School/Incomplete College; CG/IUD, Complete College/Incomplete University Degree; UD, University Degree.

epilepsy stigma score observed in Campinas was 42 (range from 2.8 to 98.6 ; SD=14.4) and, as in other regions, the SSE was influenced by socio-cultural factors, such as gender, religion social class and level of education.
It is important to highlight that expressing prejudices is very stigmatizing and people may be aware of this. For this reason, people may be reluctant to express their prejudices towards epilepsy and thus may hide the full extent of 


\section{VILA VELHA}

$\operatorname{ANOVA}(1,73)=12.90, p<0.001$

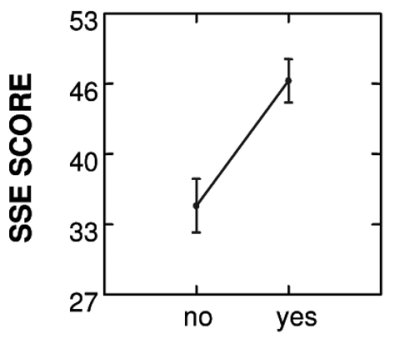

CURITIBA

ANOVA $(1,67)=3.03, p<0.001$

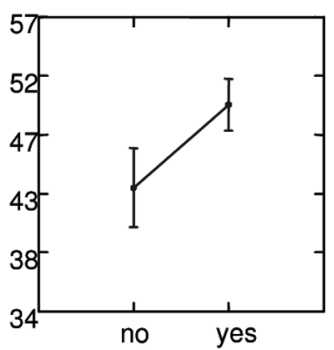

SÃO PAULO

ANOVA $(1,45)=27.55, p<0.001$

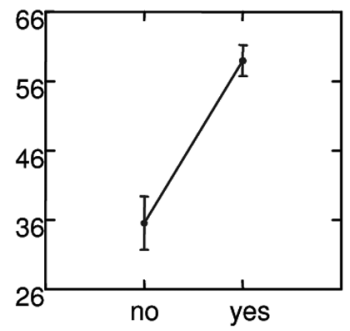

IPATINGA

ANOVA $(1,55)=13.66 p<0.001$

Do you think that people with epilepsy are stigmatized by the society?

Fig 3. Comparison between stigma perception by the individual and that perceived in society (Least Square Means).

stigma. However this may be itself be an expression of stigma. In this context, the negative stereotypes, the irrational beliefs and the community reaction towards epilepsy can emphasize discrimination behavior and ideas, reinforcing inappropriate concepts about epilepsy ${ }^{23-27}$. Additionally, it seems that when people believe in stigma, they may have prejudices, showing the existence of a strong relation among social beliefs and people's thoughts ${ }^{28,29}$.

These results confirm that epilepsy can be considered a stigmatizing condition, influencing the daily life of people with this condition. This impact may depend on the region in which each person lives. The understanding of this aspect of epilepsy is important to promote better de-stigmatization campaigns.

\section{REFERENCES}

1. Suurmeijer TP, Reuvekamp MF, Aldenkamp BP. Social functioning, psychological functioning, and quality of life in epilepsy. Epilepsia 2001;42:1160-1168.

2. Fisher RS, Vickrey BG, Gibson P et al. The impact of epilepsy from the patient's perspective. I. Descriptions and subjective perceptions. Epilepsy Res 2000;41:39-51.

3. Baker GA. The psychosocial burden of epilepsy. Epilepsia 2002;43(Suppl 6):S26-S30.

4. MacLeod JS, Austin JK. Stigma in the lives of adolescents with epilepsy: a review of the literature. Epilepsy Behav 2003;4:112-117.

5. Kim MK, Kim IK, Kim BC, Cho KH, Kim SJ, Moon JD. Positive trends of public attitudes toward epilepsy after public education campaign among rural Korean residents. J Korean Med Sci 2003;18:248-254.

6. Chung MY, Chang Y, Lai CW. Survey of public awareness, understanding, and attitudes toward epilepsy in Taiwan. Epilepsia 1995;36:488-493.

7. Fernandes PT, Li LM. Estigma na epilepsia. 1-207. 2005. Departamento de Neurologia - FCM/UNICAMP. PhD Thesis.

8. Fernandes PT, Li LM. Percepção de estigma na epilepsia. J Epilepsy Clin Neurophysiol 2006;12:207-218.

9. Fernandes PT, Salgado PC, Noronha ALA, et al. Epilepsy stigma perception in an urban area of a limited resource country. Epilepsy Behav 2007; 11:25-32.

10. Vickrey BG, Hays RD, Graber J, Rausch R, Engel J Jr., Brook RH. A health-related quality of life instrument for patients evaluated for epilepsy surgery. Med Care 1992;30:299-319.

11. Goffman E. Stigma: notes on the management of spoiled identity. New York: Touchstone, 1963.

12. Baker G. The psychosocial burden of epilepsy. Epilepsia 2002;43:26-30.

13. Baker GA. Health-related quality-of-life issues: optimizing patient outcomes. Neurology 1995;45(Suppl):S29-S34.

14. Jacoby A, Gorry J, Gamble C, Baker GA. Public knowledge, private grief: a study of public attitudes to epilepsy in the United Kingdom and implications for stigma. Epilepsia 2004;45:1405-1415.

15. Aziz H, Akhtar SW, Hasan KZ. Epilepsy in Pakistan: stigma and psychosocial problems: a population-based epidemiologic study. Epilepsia 1997;38:1069-1073.

16. Baker GA, Jacoby A, Buck D, Stalgis C, Monnet D. Quality of life of people with epilepsy: a European study. Epilepsia 1997;38:353-362.

17. Fernandes PT, Salgado PC, Noronha AL, Sander JW, Li LM. Stigma Scale of Epilepsy: validation process. Arq Neuropsiquiatr 2007;65(Supl 1):S35-S42.

18. Fernandes PT, Salgado PC, Noronha ALA, Barbosa FD, Souza EA, Li LM. Prejudice towards chronic diseases: comparison among AIDS, diabetes and epilepsy. Seizure 2007;16:320-323.

19. Fernandes PT, Salgado PC, Noronha ALA, Barbosa FD, Souza EA, Li LM. Stigma Scale of Epilepsy: conceptual issues. J Epilepsy Clin Neurophysiol 2004;10:213-218.

20. Salgado PC, Fernandes PT, Noronha ALA, Barbosa FD, Souza EA, Li LM. The second step in the construction of a Stigma Scale of Epilepsy. Arq Neuropsiquiatr 2004;63:395-398.

21. Periscinoto A. Tipos, fontes e formas de coleta de dados. In: Atlas SA (Ed). Pesquisa de Marketing. São Paulo: 1994:139-199.

22. Kleinman A, Wang WZ, Li SC, et al. The social course of epilepsy: chronic illness as social experience in interior China. Soc Sci Med 1995;40: 1319-1330.

23. Ablon J. The nature of stigma and medical conditions. Epilepsy Behav 2002;3:2-9.

24. Baker GA, Jacoby A, De Boer H, Doughty J, Myon E, Taieb C. Patients' understanding of and adjustment to epilepsy: interim findings from a European survey. Epilepsia 1999;40(Suppl 9):S26-S29.

25. McLin WM, de Boer HM. Public perceptions about epilepsy. Epilepsia 1995;36:957-959.

26. Schneider JW, Conrad P. Having epilepsy: the experience and control of illness. Philadelphia: Temple University Press, 1983.

27. Ryan R, Kempner K, Emlen AC. The stigma of epilepsy as a self-concept. Epilepsia 1980;21:433-444.

28. Fejerman N, Caraballo R. Impacto de la epilepsia en el niño y su familia. In: Devilat M (Ed). La epilepsia en LatinoAmerica. Santiago de Chile: Iku Editorial, 2000:245-54.

29. Devinsky O, Penry JK. Quality of life in epilepsy: the clinician's view. Epilepsia 1993;34(Suppl):S4-S7. 